\title{
Peningkatan Pemahaman Konsep Peserta Didik dengan Model Discovery Learning pada Materi Fungsi Invers
}

\author{
Sapilin1, Purwo Adisantoso ${ }^{2 *}$, dan Marhan Taufik ${ }^{3}$ \\ 1Pendidikan Matematika, SMA Negeri 9 Malang \\ Jalan Puncak Borobudur No. 1, Malang, Jawa Timur, Indonesia \\ sapilinwakahumas@gmail.com \\ $2^{*}$ Program Studi Pendidikan Profesi Guru, Universitas Muhammadyah Malang \\ 3Jurusan Pendidikan Matematika, Universitas Muhammadyah Malang \\ Jalan Raya Tlogomas No. 246, Malang, Jawa Timur, Indonesia \\ 2*purwo.adisantoso27@gmail.com, ${ }^{3}$ marhan@umm.ac.id
}

Artikel diterima: 31-03-2019, direvisi: 26-05-2019, diterbitkan: 31-05-2019

\begin{abstract}
Abstrak
Penelitian ini dilatarbelakangi rendahnya pemahaman konsep peserta didik. Tujuan penelitian ini untuk mendeskripsikan langkah-langkah model discovery learning dan besarnya peningkatan pemahaman konsep peserta didik tentang materi fungsi invers. Metode pengumpulan data yang digunakan dalam penelitian tindakan kelas (PTK) ini meliputi tes tulis dan observasi. Instrumen penelitian yaitu lembar soal tes akhir siklus dan lembar observasi pelaksanaan pembelajaran. Subjek penelitian adalah peserta didik kelas X IPA 6 di SMA Negeri 9 Malang sebanyak 35 peserta didik. Hasil penelitian menunjukkan bahwa terjadi peningkatan pemahaman konsep peserta didik dengan model discovery learning pada materi fungsi invers. Kemampuan pemahaman konsep peserta didik mengalami peningkatan sebesar $20,41 \%$, sedangkan ketuntasan klasikal meningkat sebesar $17,15 \%$. Pembelajaran dengan model discovery learning yang dapat meningkatkan pemahaman konsep dilaksanakan dengan langkah-langkah yaitu stimulation (memberi stimulus), problem statement (mengidentifikasi masalah), data collecting (mengumpulkan data), data processing (mengolah data), verification (memverifikasi), dan generalization (menyimpulkan). Kata Kunci: Model discovery learning, pemahaman konsep, fungsi invers.

Improved Understanding of the Concept of Learners with The Discovery Learning Model on Inverse Function Materials

Abstract

This research is motivated by the low understanding of the concepts of students. The purpose of this study is to describe the steps of the discovery learning model and the magnitude of the increase in students' understanding of the concept of inverse function material. Data collection methods used in classroom action research (CAR) include written tests and observations. The research instruments were the final cycle test questions sheet and the observation sheet of learning implementation. The research subjects were 35th-grade science students 6 in Malang State Senior High School as many as 35 students. The results of the study showed that there was an increase in understanding of students' concepts with discovery learning models in inverse function material. The ability to understand students' concepts has increased by $20.41 \%$, while classical completeness has increased by $17.15 \%$. Learning with discovery learning models that can improve understanding of concepts are carried out by steps namely stimulation (giving stimulus), problem statement (identifying problems), collecting data (collecting data), data processing (processing data), verification (verifying), and generalization (conclude).

Keywords: Discovery learning model, understanding of the concept, inverse function.
\end{abstract}




\section{Pendahuluan}

Pembelajaran matematika merupakan komunikasi dua arah, yaitu mengajar matematika dilakukan oleh pihak guru atau pendidik, sedangkan belajar matematika dilakukan oleh peserta didik. Pembelajaran matematika adalah kegiatan membelajarkan peserta didik untuk mencapai tujuan pembelajaran matematika. Tujuan pembelajaran matematika menurut Kurikulum 2013 menekankan pada dimensi pedagogik modern dalam pembelajaran, yaitu menggunakan pendekatan scientific (ilmiah) (Fuadi, Johar, \& Munzir, 2016). Dalam pembelajaran matematika, kegiatan yang dilakukan agar pembelajaran bermakna yaitu dengan mengamati, menanya, mencoba, menalar, menyaji, dan mencipta.

Penerapan pembelajaran matematika yang bermakna, diharapkan pemahaman konsep peserta didik menjadi lebih baik karena dalam mempelajari konsep baru dihubungkan dengan konsep yang telah dipelajari oleh peserta didik. Seperti yang dikemukakan oleh Nugraheni dan Sugiman (2013) bahwa mempelajari konsep matematika ibarat membangun bangunan bertingkat dimana dibutuhkan fondasi dan lantai yang kuat, begitupun mempelajari konsep matematika, dibutuhkan konsep dasar yang digunakan untuk mempelajari konsep selanjutnya. Jika peserta didik memahami konsep materi prasyarat, maka peserta didik akan mudah memahami konsep materi selanjutnya (Fajriah \& Sari, 2016).

Pemahaman konsep sangat penting dalam matematika karena merupakan dasar untuk menguasai matematika sehingga memudahkan peserta didik dalam memecahkan masalah (Luritawaty, 2018). Peserta didik dalam memahami konsep suatu materi dilakukan melalui investigasi, inkuiri, dan pemecahan masalah dari situasi dan masalah yang ada (Priyambodo, 2016).

Namun pada kenyataannya, peserta didik masih kesulitan dalam mempelajari matematika. Peserta didik beranggapan matematika merupakan mata pelajaran yang sulit, membosankan, banyak rumus, dan menakutkan (Fitri, Aima, \& Muhlisin, 2017). Peserta didik merasa kesulitan memahami konsep materi yang dipelajari karena peserta didik lebih banyak menghafal daripada memahami. Terkadang guru dalam menjelaskan juga hanya menggunakan metode ceramah. Hal ini sesuai pendapat Nasution dan Surya (2017) bahwa penggunaan metode ceramah oleh guru menimbulkan rasa bosan dan mengantuk pada peserta didik ketika belajar.

Hal ini mengakibatkan sikap pasif pada peserta didik dalam pembelajaran. Selain itu ingatan peserta didik terhadap konsepkonsep tidak membekas dengan tajam yang menyebabkan peserta didik mudah lupa dan sering kebingungan ketika memecahkan suatu masalah yang diberikan oleh guru (Rahmiati, Musdi, \& Fauzi, 2017). Hasil diskusi peneliti dengan 
guru diperoleh informasi bahwa

persentase peserta didik yang paham dengan konsep-konsep matematika juga tergolong rendah yaitu hanya $40 \%$. Kondisi ini bertolak belakang dengan tujuan peambelajaran matematika yang mengharapkan kreativitas berpikir peserta didik berkembang, sehingga terjadi peningkatan kemampuan berpikir. Peserta didik juga diharapkan mengkonstruksi pengetahuan yang baru diperoleh untuk dihubungkan dengan pengetahuan yang dimilikinya agar materi matematika mudah dipahami dan tersimpan dengan kuat dalam ingatan peserta didik. Akhirnya peserta didik senang ketika belajar matematika dan memiliki prestasi belajar yang memuaskan (Sipayung, 2018).

Untuk mengatasi permasalahan pembelajaran matematika tersebut diperlukan metode pembelajaran aktif, kreatif, dan inovatif yang dapat membuat peserta didik termotivasi dan berperan aktif dalam membangun konsep matematika. Terdapat berbagai macam metode belajar yang dapat diterapkan. Discovery learning merupakan salah satu model yang dapat digunakan. Discovery learning merupakan model pembelajaran yang mengembangkan cara belajar dimana peserta didik dituntut aktif dalam memperoleh pengetahuan dimana pengetahuan tersebut ditemukan dan diperoleh oleh peserta didik untuk dirinya sendiri (Moreno, 2018). Model discovery learning memiliki banyak kelebihan. Salah satunya adalah pengetahuan yang diperoleh peserta didik menjadi

\section{Mosharafa: Jumal Pendidikan Matematika}

Volume 8, Nomor 2, Mei 2019

Copyright @ 2019 Mosharafa: Jurnal Pendidikan Matematika pengetahuan yang bermakna karena peserta didik berusaha mencari dan menemukan sendiri pengetahuan tersebut (Effendi, 2012; Moreno, 2018).

Hasil penelitian yang menunjukkan bahwa model discovery learning dapat memberikan dampak yang positif diantaranya dilakukan oleh Moreno (2018). Hasil penelitian Moreno (2018) menunjukkan bahwa terjadi perbaikan proses pembelajaran dan peningkatan kemampuan pemahaman matematis peserta didik kelas VII-1 SMP Negeri 25 Pekanbaru melalui penerapan model Discovery Learning.

Berdasarkan permasalahan di atas, penulis bertujuan meneliti peningkatan pemahaman konsep peserta didik dengan model Discovery Learning pada materi fungsi invers.

\section{Metode}

Pendekatan kualitatif digunakan pada penelitian ini, sedangkan jenis penelitian adalah penelitian tindakan kelas (PTK). PTK yang digunakan adalah model Kemmis dan McTaggart (Susilo, Chotimah, \& Sari, 2012) yang terdiri dari 4 tahapan yaitu: (1) perencanaan (planning), (2) tindakan (acting), (3) pengamatan (observing), dan (4) refleksi (reflecting)

Subjek dari penelitian ini adalah peserta didik kelas X IPA 6 semester 2 di SMA Negeri 9 Malang tahun pelajaran 2018/2019 yang berjumlah 35 peserta didik (16 laki-laki dan 19 perempuan). Tempat yang digunakan sebagai tempat 
penelitian dalam penelitian ini adalah SMA Negeri 9 yang beralamat di Jalan Puncak Borobudur No. 1 Kota Malang, Jawa Timur.

Metode pengumpulan data menggunakan dua cara yaitu tes tulis dan observasi. Tes tulis dilakukan dengan tujuan untuk mengetahui pemahaman konsep peserta didik setelah mengikuti pembelajaran dengan model discovery learning. Tes tulis dilaksanakan sebanyak dua kali. Tes pertama merupakan tes akhir siklus I dengan materi menemukan rumus fungsi invers, sedangkan tes kedua merupakan tes akhir siklus II dengan materi invers fungsi komposisi. Kegiatan observasi mempunyai dua tujuan yaitu untuk mengetahui kesesuaian antara rencana tindakan dan pelaksanaan tindakan serta mengamati aktivitas siswa selama pembelajaran. Observasi terhadap peneliti (guru) dan kegiatan peserta didik dilakukan oleh guru mata pelajaran matematika dan teman sejawat.

Instrumen penelitian pada penelitian ini yaitu lembar soal tes akhir siklus dan lembar observasi pelaksanaan pembelajaran. Lembar soal tes akhir siklus yang digunakan adalah soal tes berbentuk uraian materi fungsi invers yang telah disesuaikan dengan indikator pemahaman konsep peserta didik. Lembar observasi yang digunakan adalah lembar observasi pelaksanaan pembelajaran dengan menggunakan model discovery learning. Selain menggunakan lembar observasi juga menggunakan catatan lapangan. Catatan lapangan dimaksudkan sebagai pelengkap data yang digunakan untuk 288 mendeskripsikan kegiatan pembelajaran yang meliputi aktivitas guru dan siswa yang belum ada pada lembar observasi, sehingga tidak ada data yang terlewatkan.

Analisis data penelitian ini dilakukan selama dan setelah pengumpulan data. Data penelitian yang terkumpul dianalisis dengan model alir (flow model) Milles dan Huberman (Sugiyono, 2011) yang meliputi: (a) mereduksi data, (b) menyajikan data, dan (c) menarik kesimpulan.

Kriteria keberhasilan tindakan meliputi dua komponen yaitu kriteria keberhasilan proses dan kriteria keberhasilan pemahaman konsep sebagai berikut: (1) Keberhasilan proses berdasarkan lembar observasi oleh pengamat. Analisis data hasil observasi berupa analisis persentase. Jumlah keseluruhan skor yang diperoleh dari masing-masing deskriptor disebut jumlah skor. Selanjutnya dihitung persentase nilai rata-ratanya dengan rumus sebagai berikut.

$$
\begin{gathered}
\text { Persentase Nilai Rata }- \text { Rata }(N R) \\
=\frac{\text { Jumlah Skor }}{\text { Skor Maksimal }} \times 100 \%
\end{gathered}
$$

Jika NR mencapai minimal 80\%, maka kriteria siklus pelaksanaan tindakan dapat dikatakan berhasil dan siklus dapat dihentikan. Kriteria taraf keberhasilan proses dapat ditentukan pada tabel 1.

Tabel 1. Kriteria Keberhasilan Proses

\begin{tabular}{ccc|}
\hline No & Interval & Kriteria \\
\hline 1. & $90 \% \leq \mathrm{NR} \leq 100 \%$ & Sangat Baik \\
\hline 2. & $80 \% \leq \mathrm{NR}<90 \%$ & Baik \\
\hline 3. & $70 \% \leq \mathrm{NR}<80 \%$ & Cukup \\
\hline 4. & $60 \% \leq \mathrm{NR}<70 \%$ & Kurang \\
\hline 5. & $0 \% \leq \mathrm{NR}<60 \%$ & Sangat Kurang \\
\hline
\end{tabular}

Mosharafa: Jumal Pendidikan Matematika Volume 8, Nomor 2, Mei 2019 Copyright $\odot 2019$ Mosharafa: Jurnal Pendidikan Matematika 
(2) Keberhasilan pemahaman konsep dilihat dari nilai rata-rata kelas dan ketuntasan belajar. Nilai rata-rata kelas Ketuntasan hasil belajar di SMA Negeri 9 Malang memiliki kriteria ketuntasan minimal (KKM) sebesar 80 yang mencakup semua indikator pemahaman konsep. Kelas dinyatakan tuntas belajar jika presentase ketuntasan belajar peserta didik tidak kurang dari $80 \%$ dari jumlah keseluruhan peserta didik yang mengikuti tes. Perhitungan persentase skor siswa yang tuntas belajar adalah sebagai berikut.

$$
P=\frac{n}{N} \times 100 \%
$$

Keterangan:

$\mathrm{P}=$ prosentase peserta didik yang tuntas belajar.

$\mathrm{n}=$ banyaknya peserta didik yang tuntas belajar.

$\mathrm{N}=$ banyaknya peserta didik.

Suatu siklus dapat dikatakan berhasil jika kedua kriteria keberhasilan tercapai. Akan tetapi jika tidak tercapai maka dilanjutkan dengan siklus selanjutnya.

\section{Hasil dan Pembahasan}

Penelitian ini dilakukan dalam dua siklus dengan setiap siklus terdiri dari dua pertemuan dan satu kali tes akhir siklus. Pembelajaran pada penelitian ini menerapkan model discovery learning dengan enam langkah yaitu stimulation (memberi stimulus), problem statement (mengidentifikasi masalah), data collecting (mengumpulkan data), data processing (mengolah data), verification

Mosharafa: Jumal Pendidikan Matematika Volume 8, Nomor 2, Mei 2019

Copyright @ 2019 Mosharafa: Jurnal Pendidikan Matematika (memverifikasi), dan generalization (menyimpulkan).

Pada tahap stimulation, guru memberikan apersepsi berupa tujuan pembelajaran, materi prasyarat, aplikasi, dan pentingnya materi yang dipelajari. Peserta didik tampak serius memperhatikan penjelasan guru. Peserta didik terdorong untuk melaksanakan pembelajaran dengan aktif ketika mereka telah mengetahui tujuan dari pembelajaran yang mereka ikuti (Rusman, 2013).

Guru kemudian membagi kelas menjadi beberapa kelompok dan membagikan UKBM (Unit Kegiatan Belajar Mandiri) kepada setiap peserta didik. Peserta didik kurang setuju dengan kelompok yang dibuat oleh guru karena mereka menginginkan peserta didik yang menentukan. Guru menjelaskan bahwa pembagian kelompok telah heterogen kemampuannya. Kelompok yang heterogen baik dalam kemampuan maupun sosial memungkinkan peserta didik untuk saling berdiskusi (Suprihatiningrum, 2013).

Setelah berkumpul dengan kelompoknya, guru melanjutkan pada tahap problem statement. Peserta didik dengan bimbingan guru menemukan permasalahan yang akan diselesaikan, yaitu menemukan rumus invers suatu fungsi. Melalui pembelajaran menggunakan model discovery learning, maka peserta didik dituntun untuk menemukan sendiri tentang konsep yang dipelajari. Sejalan dengan pendapat 
Yurniwati dan Hanum (2017) bahwa dengan menggunakan model discovery learning, peserta didik dituntut untuk melakukan observasi, diskusi, komunikasi, dan menarik kesimpulan sendiri.

Untuk menyelesaikan permasalahan menentukan rumus invers suatu fungsi, maka peserta didik masuk ke tahap selanjutnya yaitu tahap data collecting. Pada tahap ini peserta didik diberi kesempatan oleh guru untuk mencari materi dan hal-hal yang diperlukan untuk menyelesaikan masalah dari berbagai sumber.

Selanjutnya peserta didik melanjutkan pada tahap data processing. Pada tahap ini peserta didik secara berkelompok menyelesaikan masalah pada UKBM. Beberapa kelompok mengalami kesulitan dan bertanya kepada guru karena peserta didik belum terbiasa menggunakan model discovery learning. Guru tidak langsung memberikan jawaban, tetapi memberikan pertanyaan pancingan yang mengarahkan peserta didik menuju solusi yang ditanya oleh peserta didik.

Tahap selanjutnya yaitu tahap verification. Pada tahap ini guru meminta perwakilan salah satu kelompok untuk mempresentasikan hasil diskusi kelompoknya. Peserta didik saling menunjuk ketika diminta presentasi. Hal ini terjadi karena peserta didik kurang percaya diri dan belum terbiasa berbicara di depan kelas. Guru memberi stimulus agar peserta didik berani presentasi di depan kelas.
Pada akhir presentasi, guru memberi kesempatan untuk bertanya jika terdapat perbedaan dan jika ada yang belum dipahami. Ini merupakan tahap generalization. Guru memberi penguatan dan menyimpulkan hasil presentasi bersama peserta didik satu kelas. Penguatan yang diberikan oleh guru dengan segera membuat peserta didik terdorong untuk belajar dengan semangat dan giat (Dimyati \& Mudjiono, 2013).

Pada pertemuan selanjutnya diberikan tes akhir siklus I untuk mengetahui pemahaman konsep peserta didik. Hasil tes akhir siklus dianalisis untuk mengetahui persentase ketuntasan secara klasikal serta untuk mengetahui pemahaman konsep peserta didik. Analisis hasil tes akhir siklus I ditunjukkan pada tabel 2.

Pada tabel 2, terlihat bahwa peserta didik yang memenuhi KKM berjumlah 23 peserta didik $(65,71 \%)$ sedangkan peserta didik yang tidak memenuhi KKM berjumlah 12 peserta didik (34,29\%). Nilai rata-rata yang diperoleh peserta didik adalah 75,57.

Penerapan model discovery learning selain melihat dari nilai hasil tes siklus I juga dilihat aktivitas guru beserta peserta didik. Aktivitas guru beserta peserta didik

Tabel 2.

\begin{tabular}{llcc|}
\multicolumn{4}{c}{ Analisis Hasil Tes Siklus Siklus I } \\
\hline No & Keterangan & Nilai & Persentase \\
\hline 1. & $\begin{array}{l}\text { Jumlah siswa yang } \\
\text { tuntas }\end{array}$ & 23 & $65,71 \%$ \\
\hline 2. & $\begin{array}{l}\text { Jumlah siswa yang } \\
\text { tidak tuntas }\end{array}$ & 12 & $34,29 \%$ \\
\hline & Rata-rata nilai & 75,57 & \\
\hline
\end{tabular}


dilihat menggunakan lembar observasi. Hasil analisis aktivitas guru ditunjukkan pada tabel 3.

Pada pertemuan pertama, skor masksimal yang dapat diperoleh adalah 52, sedangkan pada pertemuan kedua adalah 48. Berdasarkan hasil analisis aktivitas guru menunjukkan bahwa persentase pertemuan pertama sebesar $80,13 \%$ pada kriteria baik dan persentase pertemuan kedua sebesar $82,75 \%$ pada kriteria baik. Hasil ini menunjukkan bahwa pada siklus I rata-rata aktivitas guru sebesar $81,44 \%$ sudah sesuai dengan lembar observasi dan RPP serta berada pada kriteria baik.

Hasil analisis aktivitas peserta didik pada siklus I menggunakan lembar observasi peserta didik ditunjukkan pada tabel 4.

Pada pertemuan pertemuan pertama, skor masksimal yang dapat diperoleh adalah 52, sedangkan pada pertemuan kedua adalah 48. Berdasarkan hasil analisis aktivitas peserta didik menunjukkan bahwa persentase pertemuan pertama sebesar 79,49\% pada kriteria cukup dan persentase pertemuan kedua sebesar

Tabel 3.

Analisis Hasil Lembar Observasi Guru Siklus I

\begin{tabular}{|crccccc|}
\hline \multirow{2}{*}{ No } & \multirow{2}{*}{\begin{tabular}{c} 
Pengamatan \\
\cline { 3 - 6 }
\end{tabular}} & \multicolumn{2}{c}{$\begin{array}{c}\text { Pertemuan } \\
\text { Pertama }\end{array}$} & \multicolumn{2}{c}{$\begin{array}{c}\text { Pertemuan } \\
\text { Kedua }\end{array}$} \\
\cline { 2 - 6 } & Skor & $\%$ & Skor & $\%$ \\
\hline 2 & Kedua & 39 & 75,00 & 40 & 83,33 \\
\hline 3 & Ketiga & 37 & 71,15 & 39 & 71,15 \\
\hline & Rata-rata & & 80,13 & & 82,75 \\
\hline & Kategori & & Baik & & Baik \\
\hline
\end{tabular}

Mosharafa: Jumal Pendidikan Matematika

Volume 8, Nomor 2, Mei 2019

Copyright @ 2019 Mosharafa: Jurnal Pendidikan Matematika
81,94\% pada kriteria baik. Hasil ini menunjukkan bahwa pada siklus I rata-rata aktivitas peserta didik sebesar 80,72\% sudah sesuai dengan lembar observasi dan RPP serta berada pada kriteria baik.

Setelah melakukan analisis baik pada hasil tes siklus I, aktivitas guru, dan aktivitas peserta didik, diperoleh kesimpulan bahwa siklus II perlu dilakukan. Siklus II dilakukan dengan memperbaiki kekurangan pada siklus I.

Kegiatan pembelajaran pada siklus II tetap menerapkan model discovery learning dengan melakukan perbaikan dari hasil refleksi siklus I. Pembelajaran model discovery learning diawali dengan tahap stimulus. Guru menyampaikan tujuan pembelajaran, materi prasyarat, aplikasi, dan pentingnya materi yang dipelajari. Guru mempersingkat apersepsi yang disampaikan sesuai hasil refleksi pada siklus I.

Tahap problem statement, peserta didik menentukan permasalahan yang akan diselesaikan yaitu tentang invers dari fungsi komposisi. Peserta didik membentuk kelompok sesuai instruksi

Tabel 4.

Analisis Hasil Lembar Observasi Peserta Didik Siklus I

\begin{tabular}{|clcccc|}
\hline \multirow{2}{*}{ No } & \multirow{2}{*}{ Pengamatan } & \multicolumn{2}{c}{$\begin{array}{c}\text { Pertemuan } \\
\text { Pertama }\end{array}$} & \multicolumn{2}{c}{$\begin{array}{c}\text { Pertemuan } \\
\text { Kedua }\end{array}$} \\
\cline { 3 - 6 } & & Skor & $\%$ & Skor & $\%$ \\
\hline 1 & Pertama & 50 & 96,15 & 45 & 93,75 \\
\hline 2 & Kedua & 37 & 71,15 & 38 & 79,17 \\
\hline 3 & Ketiga & 37 & 71,15 & 35 & 72,92 \\
\hline & Rata-rata & & 79,49 & & 81,94 \\
\hline & Kategori & & Cukup & & Baik \\
\hline
\end{tabular}


guru. Pembentukan kelompok disesuaikan dengan hasil tes siklus I. Untuk lebih mengefektifkan jalannya diskusi kelompok, guru memberi saran kepada setiap kelompok untuk menunjuk ketua kelompok.

Ketua kelompok merupakan peserta didik yang bertugas memberi pengarahan kepada anggota kelompok tentang masalah yang akan diselesaikan, pembagian tugas, memimpin diskusi, dan mengatur agar semua anggota aktif berdiskusi (Anam, 2015).

Selanjutnya peserta didik melanjutkan pembelajaran pada tahap data collecting. Peserta didik tetap diberi kesempatan mencari materi dan hal-hal yang berhubungan dengan permasalahn yang akan diselesaikan dari berbagai sumber.

Setelah memperoleh data yang diperlukan, peserta didik memproses data tersebut untuk menyelesaikan permasalahan pada UKBM. Peserta didik saling berdiskusi dalam kelompoknya. Tahap ini merupakan tahap data processing. Guru mengingatkan semua kelompok untuk saling aktif berdiskusi dalam menyelesaikan masalah pada UKBM.

Pada tahap verification, guru meminta perwakilan kelompok untuk mempresentasikan hasil diskusi kelompoknya. Peserta didik langsung maju dan mempresentasikan hasil diskusinya. Peserta didik tidak lagi saling menunjuk. Hal ini terjadi karena guru selalu memberi motivasi kepada peserta didik agar percaya diri ketika presentasi. Sejalan 292 dengan pendapat Dimyati dan Mudjiono (2013) bahwa guru perlu memberi motivasi kepada peserta didik untuk percaya diri dapat mengatasi segala hambatan.

Di akhir presentasi, guru memberi kesempatan bertanya bagi peserta didik. Guru juga memberi penegasan dari hasil presentasi peserta didik. Kegiatan ini merupakan tahap generalization. Peserta didik dengan bimbingan guru menyimpulkan hasil pembelajaran. Melalui kegiatan penyimpulan, diharapkan peserta didik dapat mengingat kembali keseluruhan materi pembelajaran yang telah dipelajari (Sanjaya, 2011).

Pada pertemuan selanjutnya, diadakan tes siklus II. Hasil tes siklus II dianalisis dan ditunjukkan pada tabel 5 .

Pada tabel 5, terlihat bahwa peserta didik yang memenuhi KKM berjumlah berjumlah 29 peserta didik (82,86\%) sedangkan peserta didik yang tidak memenuhi KKM berjumlah 6 peserta didik $(17,14 \%)$. Nilai rata-rata yang diperoleh peserta didik adalah 88,91.

Analisis nilai hasil tes siklus I dan siklus II juga menunjukkan bahwa terjadi peningkatan jumlah peserta didik yang memenuhi KKM serta rata-rata nilai tes

Tabel 5. Analisis Hasil Tes Siklus II

\begin{tabular}{llcc}
\hline No & Keterangan & Nilai & Persentase \\
\hline 1. & $\begin{array}{l}\text { Jumlah siswa } \\
\text { yang tuntas }\end{array}$ & 29 & $82,86 \%$ \\
\hline 2. & $\begin{array}{l}\text { Jumlah siswa } \\
\text { yang tidak } \\
\text { tuntas }\end{array}$ & 6 & $17,14 \%$ \\
\hline & Rata-rata nilai & 88,91 & \\
\hline
\end{tabular}

Mosharafa: Jurnal Pendidikan Matematika Volume 8, Nomor 2, Mei 2019 Copyright $\odot 2019$ Mosharafa: Jurnal Pendidikan Matematika 
siklus. Analisis nilai hasil tes siklus I dan siklus II ditunjukkan pada tabel 6 .

Berdasarkan tabel 6, jumlah peserta didik yang memenuhi KKM sebanyak 23 peserta didik $(65,71 \%)$ pada siklus I dan 29 peserta didik $(82,86 \%)$ pada siklus II, sehingga terjadi peningkatan peserta didik yang memenuhi KKM sebanyak 6 peserta didik (7,15\%). Rata-rata nilai siklus I sebesar 75,57 meningkat menjadi 88,91 pada siklus II, sehingga terjadi peningkatan sebesar 13,34. Dengan demikian dapat disimpulkan bahwa materi yang diajarkan lebih mudah dipahami oleh peserta didik. Hal ini disebabkan model discovery learning mendorong peserta didik untuk menemukan sendiri konsep yang dipelajari. Dengan menemukan sendiri konsep yang dipelajari, maka konsep tersebut akan lebih membekas dalam ingatan peserta didik (In'am \& Hajar, 2017).

Pemahaman konsep peserta didik dilihat dari hasil tes akhir siklus I dan siklus Il yang didasarkan pada indikator pemahaman konsep menurut Fajriah \& Sari, 2016; Lestari \& Surya (2017). Indikator pemahaman konsep tersebut ditunjukkan pada tabel 7.

Tabel 6.

Tabel Analisis Hasil Tes Siklus I dan Siklus II

\begin{tabular}{|llcccc|}
\hline \multirow{2}{*}{ No } & Keterangan & \multicolumn{3}{c}{ Siklus I } & \multicolumn{2}{c|}{ Siklus II } \\
\cline { 3 - 6 } & & Nilai & $\%$ & Nilai & $\%$ \\
\hline 1. & $\begin{array}{l}\text { Jumlah siswa } \\
\text { yang tuntas }\end{array}$ & 23 & 65,71 & 29 & 82,86 \\
\hline 2. & $\begin{array}{l}\text { Jumlah siswa } \\
\text { yang tidak tuntas }\end{array}$ & 12 & 34,29 & 6 & 17,14 \\
\hline & Rata-rata nilai & 75,57 & 88,91 \\
\hline
\end{tabular}

Analisis hasil tes siklus | dan siklus || berdasarkan indikator pemahaman konsep disajikan menggunakan diagram pada gambar 1.

Berdasarkan grafik pada gambar 1 terlihat bahwa terjadi peningkatan persentase pada setiap indikator. Indikator I1 meningkat sebesar 2,86\% dari 94,29\% menjadi $97,14 \%$. Indikator 12 meningkat sebesar $14,29 \%$ dari $80 \%$ menjadi 94,29\%. Indikator 13 meningkat sebesar 5,71\% dari $85,71 \%$ menjadi 91,43\%. Indikator 14 meningkat sebesar $62,86 \%$ dari $25,71 \%$ menjadi $88,57 \%$. Indikator 15 meningkat sebesar $17,14 \%$ dari $77,14 \%$ menjadi 94,29\%. Indikator 16 meningkat sebesar $22,86 \%$ dari $77,14 \%$ menjadi $100 \%$. Indikator 17 meningkat sebesar 17,15\% dari $77,14 \%$ menjadi 94,29\%. Rata-rata indikator pemahaman konsep siklus II

Tabel 7.

Indikator Pemahaman Konsep

\begin{tabular}{|lcl|}
\hline No & $\begin{array}{c}\text { Kode } \\
\text { Indikator }\end{array}$ & Indikator Pemahaman Konsep \\
\hline 1. & 11 & $\begin{array}{l}\text { Menyatakan ulang sebuah } \\
\text { konsep }\end{array}$ \\
\hline 2. & 12 & $\begin{array}{l}\text { Mengklasifikasi objek-objek } \\
\text { menurut sifat-sifat tertentu } \\
\text { (sesuai dengan konsepnya) }\end{array}$ \\
\hline 3. & 13 & $\begin{array}{l}\text { Memberi contoh dan non- } \\
\text { contoh dari konsep }\end{array}$ \\
\hline 4. & 14 & $\begin{array}{l}\text { Menyajikan konsep dalam } \\
\text { berbagai bentuk representasi } \\
\text { matematis }\end{array}$ \\
\hline 5. & 15 & $\begin{array}{l}\text { Mengembangkan syarat perlu } \\
\text { atau syarat cukup suatu } \\
\text { konsep }\end{array}$ \\
\hline 7. & 16 & $\begin{array}{l}\text { Menggunakan, } \\
\text { memanfaatkan, dan memilih } \\
\text { prosedur atau operasi tertentu }\end{array}$ \\
\hline
\end{tabular}


meningkat sebesar 20,41\% dibandingkan siklus I yaitu dari $73,88 \%$ pada siklus । menjadi 94,29\% pada siklus II.

Analisis aktivitas guru dan peserta didik pada siklus I dan siklus II dilakukan untuk mengetahui peningkatan penerapan model discovery learning. Analisis aktivitas guru dan peserta didik pada siklus I dan siklus II ditunjukkan pada tabel 8.

Berdasarkan tabel 8, terlihat bahwa terjadi peningkatan persentase keterlaksanaan model discovery learning dari siklus I ke siklus II. Hal ini terjadi karena pada model discovery learning terjadi diskusi antara guru dan peserta didik. Peserta didik diharuskan aktif berdiskusi dalam menemukan sebuah konsep. Sejalan dengan pendapat bahwa model discovery learning merupakan

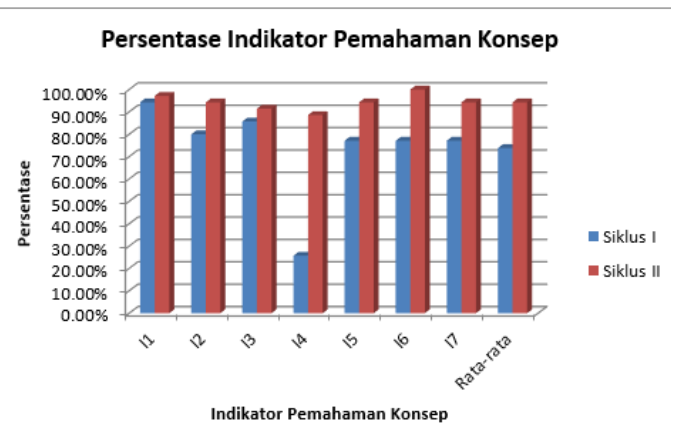

Gambar 1. Grafik Persentase Nilai MasingMasing Indikator Pemahaman Konsep.

Tabel 8.

Analisis Hasil Lembar Observasi Aktivitas Guru dan Peserta Didik

\begin{tabular}{|c|c|c|c|c|c|}
\hline \multirow{2}{*}{ No } & \multirow{2}{*}{$\begin{array}{l}\text { Jenis } \\
\text { Kegiatan }\end{array}$} & \multicolumn{2}{|c|}{ Siklus I } & \multicolumn{2}{|c|}{ Siklus II } \\
\hline & & $\%$ & Kategori & $\%$ & Kategori \\
\hline 1. & $\begin{array}{l}\text { Aktivitas } \\
\text { Guru }\end{array}$ & $81,44 \%$ & Baik & $84,14 \%$ & Baik \\
\hline 2. & $\begin{array}{l}\text { Aktivitas } \\
\text { Peserta } \\
\text { Didik }\end{array}$ & $80,72 \%$ & Baik & $84,08 \%$ & Baik \\
\hline
\end{tabular}

model pembelajaran yang memungkinkan diskusi antara guru dan peserta didik (Moreno, 2018). Hasil ini menunjukkan bahwa pembelajaran menggunakan model discovery learning dapat meningkatkan pemahaman konsep peserta didik.

Berdasarkan hasil analisis data, diperoleh bahwa pembelajaran menggunakan model discovery learning dapat meningkatkan pemahaman konsep materi fungsi invers. Langkah-langkah pembelajaran dengan model discovery learning yang dapat meningkatkan pemahaman konsep dilaksanakan dengan langkah-langkah yaitu stimulation (memberi stimulus), problem statement (mengidentifikasi masalah), data collecting (mengumpulkan data), data processing (mengolah data), verification (memverifikasi), dan generalization (menyimpulkan).

Pada tes akhir siklus I peserta didik yang mencapai KKM sebanyak 23 peserta didik dari 35 peserta didik atau sebanyak $65,71 \%$ peserta didik mencapai ketuntasan. Pada tes akhir siklus II peserta didik yang mencapai KKM sebanyak 29 peserta didik dari 35 peserta didik atau sebanyak $82,86 \%$ peserta didik mencapai ketuntasan. Dengan demikian, ketuntasan peserta didik pada siklus II terjadi peningkatan sebesar 17,15\%. Selain itu, rata-rata indikator pemahaman konsep siklus II meningkat sebesar 20,41\% dibandingkan siklus I yaitu dari 73,88\% pada siklus I menjadi 94,29\% pada siklus II, sehingga dapat disimpulkan bahwa model 
discovery learning dapat meningkatkan pemahaman konsep peserta didik.

\section{Penutup}

Berdasarkan semua data yang diperoleh dari siklus I dan siklus || sudah memenuhi kriteria keberhasilan, sehingga tidak perlu dilaksanakan siklus selanjutnya. Kriteria keberhasilan yang dimaksud adalah hasil analisis data observasi guru dan peserta didik minimal pada kriteria baik dan analisis hasil tes akhir siklus yaitu sedikitnya $80 \%$ dari banyak peserta didik dalam kelas mendapatkan nilai tes akhir siklus minimal 80 sesuai KKM di sekolah.

\section{Daftar Pustaka}

Anam, K. (2015). Pembelajaran Berbasisi Inkuiri: Metode dan Aplikasi. Yogyakarta: Pustaka Pelajar.

Dimyati, \& Mudjiono. (2013). Belajar \& Pembelajaran. Jakarta: Rineka Cipta.

Effendi, L. A. (2012). Pembelajaran Matematika Dengan Metode Penemuan Terbimbing Untuk Meningkatkan Kemampuan Representasi Dan Pemecahan Masalah Matematis Siswa Smp. Jurnal Penelitian Pendidikan, 13, 1-10.

Fajriah, N., \& Sari, D. (2016). Meningkatkan Pemahaman Konsep Matematis Siswa Pada Materi SPLDV Melalui Model Pembelajaran Kooperatif Tipe Think-Pair-Share Di Kelas VIII SMP. EDU-MAT Jurnal Pendidikan Matematika, 4(April), 6875.

Fitri, D. Y., Aima, Z., \& Muhlisin. (2017). Pengaruh Penerapan Teknik Spotlight Terhadap Pemahaman Konsep Matematis Siswa Kelas VIII SMPN 1
Batang Anai Padang Pariaman. Mosharafa: Jurnal Pendidikan Matematika, 6(2), 247-254.

Fuadi, R., Johar, R., \& Munzir, S. (2016). Peningkatkan Kemampuan

Pemahaman dan Penalaran Matematis melalui Pendekatan Kontekstual. Jurnal Didaktika Matematika, 3(1), 47-54.

In'am, A., \& Hajar, S. (2017). Learning Geometry through Discovery Learning Using a Scientific Approach. International Journal of Instruction, 10(01), 55-70. https://doi.org/10.12973/iji.2017.101 $4 a$

Lestari, L., \& Surya, E. (2017). The Effectiveness of Realistic Mathematics Education Approach on Ability of Students' Mathematical Concept Understanding. International Journal of Sciences: Basic and Applied Research (IJSBAR), 34(1), 91-100.

Luritawaty, I. P. (2018). Pembelajaran Take And Give Dalam Upaya Mengembangkan Kemampuan Pemahaman Konsep Matematis. Mosharafa: Jurnal Pendidikan Matematika, 7(2), 179-188.

Moreno, L. (2018). Penerapan Model Discovery Learning Untuk Meningkatkan Kemampuan Pemahaman Matematis Siswa Kelas VII SMPN 25 Pekanbaru. Jurnal Pendidikan Tambusai, 2, 1401-1428.

Nasution, F. S., \& Surya, E. (2017). Efforts to Increase Student Learning Results with Cooperative Learning Type Learning Model Think Pair Share on the Cube and Beams Materials in Class VIII SMP Kartika I-1 Medan. International Journal of Sciences: Basic and Applied Research (IJSBAR), 
33(3), 280-290.

Nugraheni, E. A., \& Sugiman. (2013). Pengaruh Pendekatan PMRI terhadap Aktivitas dan Pemahaman Konsep Matematika Siswa SMP. Pythagoras, 8(1), 101-108. Retrieved from http://journal.uny.ac.id/index.php/py thagoras\%0APengaruh

Priyambodo, S. (2016). Peningkatan Kemampuan Pemahaman Konsep Matematis Siswa dengan Metode Pembelajaran Personalized System of Instruction. Mosharafa: Jurnal Pendidikan Matematika, 5(1), 10-17. Rahmiati, Musdi, E., \& Fauzi, A. (2017). Pengembangan Perangkat Pembelajaran Matematika Berbasis Discovery Learning Untuk Meningkatkan Kemampuan Pemecahan Masalah Siswa Kelas VIII SMP. Mosharafa: Jurnal Pendidikan Matematika, 6(2), 267-272.

Rusman. (2013).

Model-Model

Pembelajaran Mengembangkan Profesionalisme Guru. Jakarta: Rajawali Press.

Sanjaya, W. (2011). Strategi Pembelajaran Berorientasi Standar Proses Pendidikan. Jakarta: Kencana Prenada Media.

Sipayung, A. (2018). Meningkatkan Pemahaman Konsep Matematika Tentang Sifat-Sifat Bangun Ruang Sederhana Melalui Contextual Teaching and Learning. Mosharafa: Jurnal Pendidikan Matematika, 7(3), 401-412.

Sugiyono. (2011). Metode Penelitian Pendidikan (Pendekatan Kuantitatif, Kualitatif, dan $R$ \& D). Bandung: Alfabeta.

Suprihatiningrum, J. (2013). Strategi Pembelajaran: Teori \& Aplikasi.
Jogjakarta: Ar-Ruzz Media.

Susilo, H., Chotimah, H., \& Sari, Y. D. (2012). Penelitian Tindakan Kelas sebagai Sarana Pengembangan Keprofesionalan Guru dan Calon Guru. Malang: Bayumedia.

Yurniwati, \& Hanum, L. (2017). Improving Mathematics Achievement of Indonesian 5th Grade Students Through Guided Discovery Learning. Journal on Mathematics Education, 8(1), 77-84. https://doi.org/10.22342/jme.8.1.320 9.77-84

\section{Riwayat Hidup Penulis Drs. Sapilin}

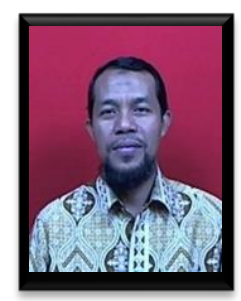

Lahir di Lamongan, 7 Agustus 1963. Guru pengajar di SMA Negeri 9 Malang, Jawa Timur. Studi S1 Pendidikan Matematika Fakultas Matematika dan Ilmu Pengetahuan Alam IKIP Negeri Malang.

\section{Purwo Adisantoso, S.Pd.}



Lahir di Malang, 14 Juli 1990. Alumni prodi Pendidikan Matematika Universitas Kanjuruhan Malang, ini merupakan mahasiswa Pendidikan Profesi Guru Prajabatan Universitas Muhammadiyah Malang tahun 2018.

\section{Drs. Marhan Taufik, M.Si.}

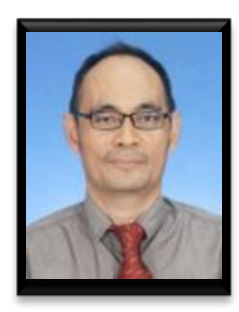

Lahir di Palembang, 5 Oktober 1965. Dosen pengajar pendidikan matematika Universitas Muhammadiyah Malang. Studi S1 Pendidikan Matematika Universitas Sriwijaya; Studi S2 Matematika Institut Teknologi Bandung. 